\title{
IMPLEMENTASI SISTEM CERDAS PENGONTROL DAN MONITORING MCB PANEL LISTRIK PLN SECARA TERPUSAT PADA LABORATORIUM IIB DARMAJAYA
}

\author{
Ari Widiantoko ${ }^{1}$, Bayu Nugroho ${ }^{2}$ \\ ${ }^{12}$ Fakultas Ilmu komputer, Institut Informatika dan Bisnis Darmajaya \\ Jl. Z.A. Pagar Alam No.93, Bandar Lampung - Indonesia 35142 \\ ${ }^{1}$ Email : ariwidiantoko@ darmajaya.ac.id, \\ Email : bayu@darmajaya.ac.id
}

\begin{abstract}
A control system is a very important aspect in modern technology. This is a interconnection of the components in the connected or associated in such a way as to a direct order or regulate itself and another system. In IIB darmajaya electric system is still done manually, thus that personnel must make building of life and death MCB ( miniature circuit breakers and officials did not can on the monitoring of the MCB will are in a on or off. Based on these problems so there should have a system that could be implemented centrally and also made aimed to ease the users or officers can control and on the monitoring an electrical device from a distance. The design process made system made up of several components of them mikrokontroler arduino that serves as control, CT (Current Transformer) censorship as detecting an electric current, ethernet shield as a liaison tissue between the computer by arduino and relay (Magnetic Contactor) as a switch. Thus, the result of this research is the control system and on the monitoring an electrical device on MCB centrally. Thus the building only will no longer around to check mcb installed at every building as the use of electricity in line with the needs so as to diminish electricity consumption will have.
\end{abstract}

Keywords : Microcontroler Aduino, Ethernet Shield, System Control, MCB

\begin{abstract}
ABSTRAK
Sistem kontrol adalah aspek yang sangat penting dalam teknologi moderen. Ini adalah sebuah interkoneksi dari komponen terhubung atau terkait sedemikian rupa untuk perintah langsung atau mengatur diri sendiri maupun sistem lain. Di IIB darmajaya, sistem kelistrikan masih dilakukan secara manual sehingga petugas harus berkeliling gedung untuk menghidupkan dan mematikan MCB (Miniature Circuit Breakers) serta petugas tidak dapat memonitoring MCB manakah yang masih dalam keadaan on atau Off. Berdasarkan permasalahan tersebut maka perlu adanya suatu sistem yang dapat diimplementasikan secara terpusat dan juga dibuat bertujuan untuk memudahkan para pengguna atau petugas dapat mengendalikan dan memonitoring perangkat listrik dari jarak jauh. Proses perancangan sistem dibuat terdiri dari beberapa komponen diantaranya mikrokontroler arduino yang berfungsi sebagai pengontrol, CT (Current Transformer) sensor sebagai pendeteksi arus listrik, ethernet shield sebagai penghubung jaringan antara komputer dengan arduino dan relay (kontaktor magnet) sebagai saklar. Hasil dari penelitian ini adalah sistem pengendali dan memonitoring perangkat listrik pada $\mathrm{MCB}$ secara terpusat, sehingga petugas tidak perlu lagi berkeliling gedung hanya untuk mengecek $\mathrm{MCB}$ yang terpasang pada setiap gedung serta dapat menggunakan listrik sesuai dengan kebutuhan sehingga dapat mengurangi pemakaian listrik yang tidak berguna.
\end{abstract}

Kata kunci : Mikrokontroler Arduino, Ethernet Shield, Sistem kontrol, MCB 


\section{PENDAHULUAN}

Perkembangan teknologi sungguh sangat cepat di era digital seperti saat ini. Segala sesuatu semakin dibuat sedemikian rupa dan sangat efisien bagi para pengguna karena semua aktifitas manusia sudah dibuat segala sesuatunya menjadi lebih mudah. Pada penelitian ini akan dilakukannya pengendalian dan monitoring listrik melalui MCB yang terpasang pada gedung laboratorium IIB darmajaya.

Penelitian ini dilakukan karena kelistrikan yang terpasang pada gedung tersebut masih bersistem manual. Pengontrolan dan pengecekan masih dilakukan oleh petugas yang piket pada hari itu dengan melakukan pengecekan seluruh gedung yang ada di IIB darmajaya, sehingga dengan sistem manual tersebut sungguh tidak praktis dan tidak efisien karena seperti kasus yang terjadi, petugas lupa mematikan listrik pada setiap gedung dan hanya membiarkannya sehingga pemakaian listrik tidak di pergunakan sebagai mana mestinya.

Dengan memanfaatkan teknologi yang ada pada saat ini kita dapat memanfaatkan arduino 2560 sebagai papan pengendali. Arduino Mega 2560 adalah papan mikro pengendali yang menggunakan mikrokontroler ATmega
2560. Arduino ini memiliki 54 digital input / output pin dimana 15 pin dapat digunakan sebagai output PWM, terdapat 16 pininput analog, 4 (empat) pin UART (port serial hardware), osilator kristal 16 MHz, koneksi USB, jack listrik, header ICSP, dan tombol reset. Arduino ini terhubung ke komputer dengan kabel USB atau dengan adaptor AC-DC dan baterai. [1].

Sebagai pengirim perintah pengendalian sistem dapat digunakan ethernet shield sebagai media pentransmisian data. Ethernet Shield adalah modul yang digunakan untuk mengkoneksikan Arduino dengan internet menggunakan kabel (Wired). Arduino Ethernet Shield dibuat berdasarkan pada Wiznet W5100 ethernet chip. Wiznet W5100 menyediakan IP untuk TCP dan UDP, yang mendukung hingga 4 socket secara simultan. Untuk menggunakanya dibutuhkan library Ethernet dan SPI. Dan Ethernet Shield ini menggunakan kabel RJ-45 untuk mengkoneksikanya ke Internet, dengan integrated line transformer dan juga Power over Ethernet [2].

Kontaktor magnet digunakan sebagai penyambung dan pemutus rangkaian, yang dapat dikendalikan dari jarak jauh. Pergerakan kontak-kontaknya terjadi karena adanya gaya elektromagnet. 
Magnet berfungsi sebagai penarik dan pelepas kontak-kontak. Kumparan atau belitan magnet (coil) suatu kontaktor magnet dirancang untuk arus searah (DC) saja atau arus bolak-balik (AC) saja. [3]

CT (Current Transformer) digunakan sebagai alat pendeteksi arus lisrtrik yang menghasilkan arus di sekunder dimana besarnya sesuai dengan ratio dan arus primernya. Pada dasarnya prinsip kerja transformator arus sama dengan transformator daya. Jika pada kumparan primer mengalir arus I1, maka pada kumparan primer timbul gaya gerak magnet sebesar N1.I1.Gaya gerak magnet ini memproduksi fluks pada inti, kemudian membangkitkan gaya gerak listrik (GGL) pada kumparan sekunder. Jika terminal kumparan sekunder tertutup, maka pada kumparan sekunder mengalir arus I2, arus ini menimbulkan gaya gerak magnet N1.I1 pada kumparan sekunder. [4]

\section{METODE PENELITIAN}

a. Metode

Metode air terjun atau yang sering disebutmetode waterfall sering

dinamakan siklus hidup klasik (classic life cycle), dimana hal ini menggambarkan pendekatan yang sistematis dan juga berurutan pada pengembangan perangkat lunak, dimulai dengan spesifikasi kebutuhan pengguna lalu berlanjut melalui tahapan-tahapan perencanaan (planning), permodelan (modeling), konstruksi (construction), serta penyerahan sistem ke para pelanggan/pengguna (deployment), yang diakhiri dengan dukungan pada perangkat lunak lengkap yang dihasilkan. [5]. Tahapan metode waterfall dapat dilihat pada gambar 1 (satu).

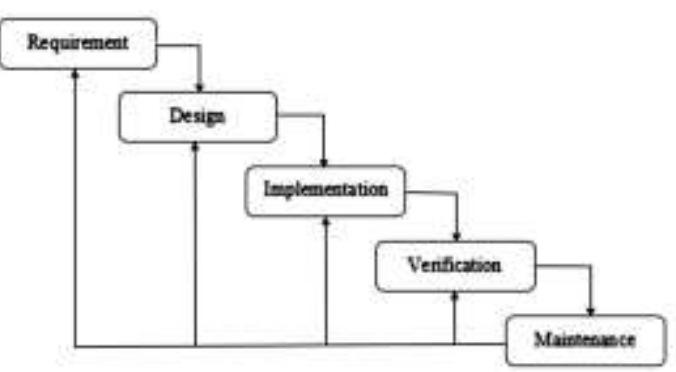

Gambar 1. Tahapan Metode Waterfall

Dalam pengembangannya metode waterfall memiliki beberapa tahapan yang berurut yaitu requirement (analisis kebutuhan), design system (desain sistem), Coding (pengkodean) dan Testing (pengujian), Penerapan Program, pemeliharaan. Tahapan tahapan dari metode waterfall adalah sebagai berikut :

\section{a. Requirement Analisis}

Tahap ini pengembang sistem diperlukan komunikasi yang bertujuan untuk memahami perangkat lunak yang diharapkan oleh pengguna dan batasan perangkat lunak tersebut. Informasi ini biasanya dapat diperoleh melalui 
wawancara, diskusi atau survei langsung. Informasi dianalisis untuk mendapatkan data yang dibutuhkan oleh pengguna.

b. System Design

Spesifikasi kebutuhan dari tahap sebelumnya akan dipelajari dalam fase ini dan desain sistem disiapkan. Desain Sistem membantu dalam menentukan perangkat keras (hardware) dan sistem persyaratan dan juga membantu dalam mendefinisikan arsitektur sistem secara keseluruhan.

\section{c. Implementation}

Pada tahap ini, sistem pertama kali dikembangkan di program kecil yang disebut unit, yang terintegrasi dalam tahap selanjutnya. Setiap unit dikembangkan dan diuji untuk fungsionalitas yang disebut sebagai unit testing.

\section{d. Verification}

Seluruh unit yang dikembangkan dalam tahap implementasi diintegrasikan ke dalam sistem setelah pengujian yang dilakukan masing-masing unit. Setelah integrasi seluruh sistem diuji untuk mengecek setiap kegagalan maupun kesalahan.

\section{e. Maintenance}

Tahap akhir dalam model waterfall. Perangkat lunak yang sudah jadi, dijalankan serta dilakukan pemeliharaan. Pemeliharaan termasuk dalam memperbaiki kesalahan yang tidak ditemukan pada langkah sebelumnya. Perbaikan implementasi unit sistem dan peningkatan jasa sistem sebagai kebutuhan baru.

1. Blok Diagram Sistem

Rancangan blok diagram sistem dalam membangun sistem cerdas pengendali lintrik PLN melalui interface terpusat dapat di lihat pada gambar 2 (dua).

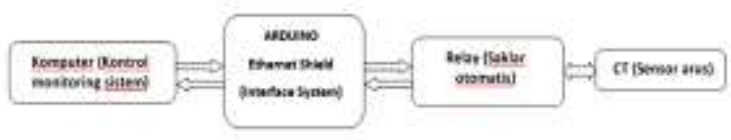

\section{Gambar 2. Blok Diagram Perancangan Sistem}

Dari gambar blok diagram dapat kita lihat komputer sebagai pengontrol dan memonitoring sistem kendali terpusat dengan terkoneksi melalui jaringan komputer dimana antara komputer dan perangkat keras dapat berkomunikasi menggunakan kabel UTP yang terhubung kepada ethernet shield sehingga arduino dapat mengolah data yang diterima. Relay atau kontaktor magnet berfungsi sebagai saklar yang berfungsi untuk menghubungkan dan memutus arus listrik yang terkontrol dalam komputer. Sedangkan CT (Current Transformer) berfungsi sebagai pendeteksi arus sehingga komputer dapat memonitoring kondisi yang ada pada lapangan.

2. Perancangan Sistem 
Perancangan sistem ini diharapkan agar dapat mengontrol dan memonitoring supaya dapat mengendalikan MCB yang terhubung oleh komputer melalui ethernet shield secara terpusat. Pertama yang dilakukan adalah perancangan perangkat lunak yang akan dibuat. Hasil perancangan perangkat lunak ditampilkan dalam diagram alir (flowchart) berikut ini:

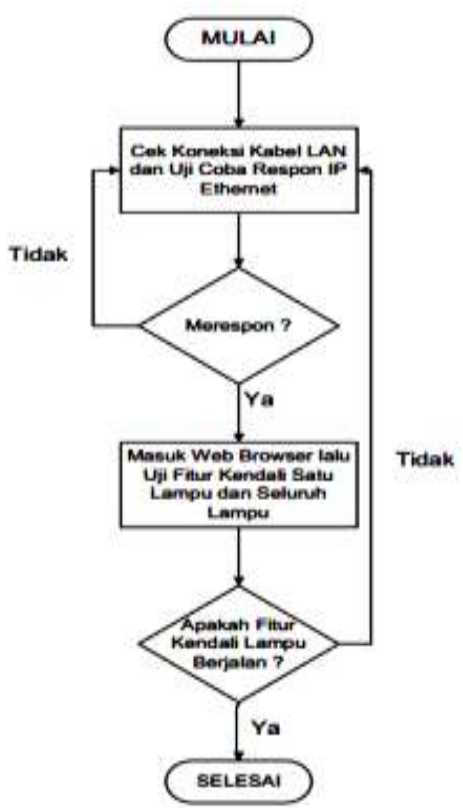

\section{Gambar 3. Flowchart Diagram Sistem}

a. Perancangan Perangkat Keras

Perancangan perangkat keras meliputi pembuatan rangkaian yang dapat menghidupkan dan mematikan listrik melaui MCB yang terpasang pada setiap panel dengan tegangan $220 \mathrm{~V}$, dalam hal ini perlu menggunakan kontaktor magnet sebagai pengganti saklar. Adapun rangkaian perangkat keras dapat di lihat pada Gambar 4.

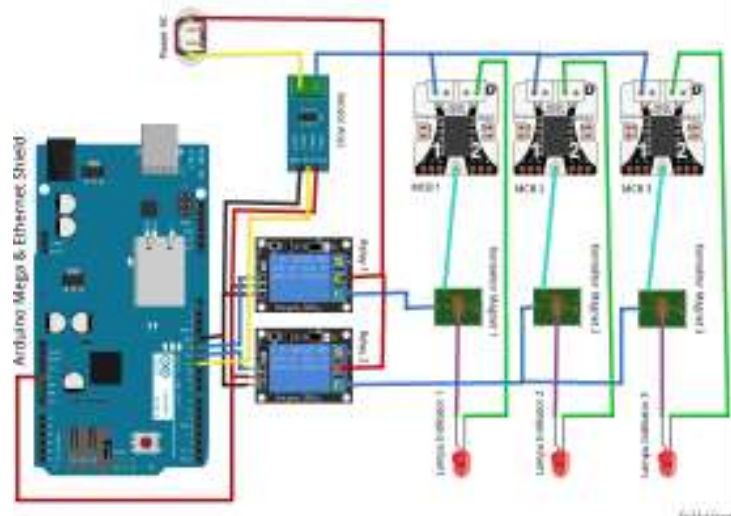

Gambar 4. Rangkaian Perangkat Keras

Pada gambar rangkaian perangkat keras dapat dilihat bahwa rangkaian sistem perangkat keras yang dirancang menggunakan 3 (tiga) buah lampu indikator dimana berfungsi sebagai indikator apakah aliran listrik sudah terputus apa tidak. Pada panel gedung terdapat 3 (tiga) buah MCB dimana masing-masing MCB berbeda fungsinya. MCB nomor 1 (satu) berfungsi untuk mengalirkan dan memutus aliran listrik lampu ruangan. MCB nomor 2 (dua) berfungsi untuk mengalirkan dan memutus arus listrik ke komputer laboratorium, sedangkan MCB nomor 3 (tiga) berfungsi untuk mengalirkan dan memutus arus listrik pada AC (Air Conditioner). CT (Current Transformer) digunakan sebagai pendeteksi arus listrik, yang berfungsi untuk memberikan data kepada arduino supaya data yang diterima oleh arduino dapat dikontrol menggunakan mikrokontroler arduino yang terhubung dengan ethernet shield dan relay shield, 
dimana arduino berfungsi sebagai pengendali atau pengontrol, Ethernet shield sebagai penghubung jaringan dan relay sebagai saklar.

\section{b. Perancangan Web Server}

Web server adalah perangkat lunak yang berfungsi sebagai penerima permintaan yang dikirimkan melalui browser kemudian memberikan tanggapan permintaan dalam bentuk halaman situs web atau lebih umumnya dalam dokumen HTML. Namun, web server dapat mempunyai dua pengertian berbeda, yaitu sebagai bagian dari perangkat keras (hardware) maupun sebagai bagian dari perangkat lunak (software)[6]. Web server digunakan untuk membangun sistem kontrol dan monitoring yg dipasang di dalam komputer. Pengujian dilakukan melalui web browser dimana pada tahapan ini digunakan web browser untuk menampilkan data status perangkat listrik (on/off), kemudian dilakukan pola pengujian dengan menekan tombol saklar di browser lalu dibandingkan dengan kondisi pada perangkat listrik apakah perangkat tersebut telah aktif jika di tekan tombol on maka lampu indikator akan menyala, jika tombol off di tekan maka lampu indikator padam.

\section{HASIL DAN PEMBAHASAN}

Pengujian implementasi alat dilakukan melalui tes koneksi antara komputer dengan perangkat hardware. Pengujian dilakukan dengan membuka aplikasi command yang sudah tertanam pada sistem operasi pada komputer dengan mengetikkan "ping 192.168.16.54", dimana alamat ip tersebut sebelumnya sudah dikonfigurasi pada perangkat. Adapun hasil pengujian dapat kita lihat pada gambar 5 (lima).

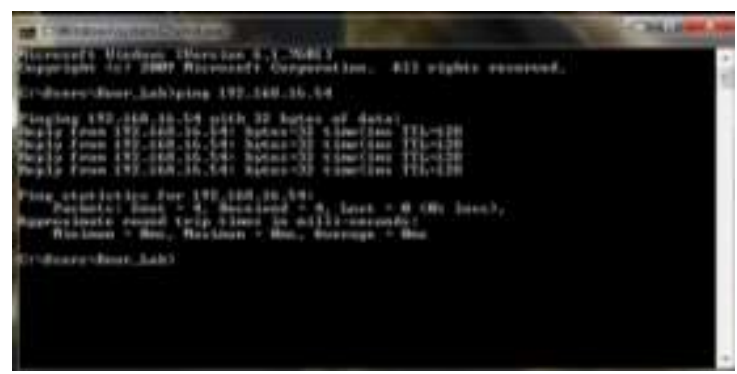

Gambar 5. Hasil Pengujian Koneksi

Pada gambar uji koneksi dapat kita lihat bahwa setelah diketikkan perintah command tersebut muncul "Reply from 192.168.16.54: $\quad$ bytes $=32 \quad$ time $<1 \mathrm{~ms}$ TTL $=128$ " menandakan bahwa komputer dan perangkat hardware terhubung dengan baik. Setelah terkoneksi antara komputer dengan perangkat keras kita bisa meguji sistem keseluruhan dengan membuka aplikasi melalui web browser seperti pada gambar 6 (enam).

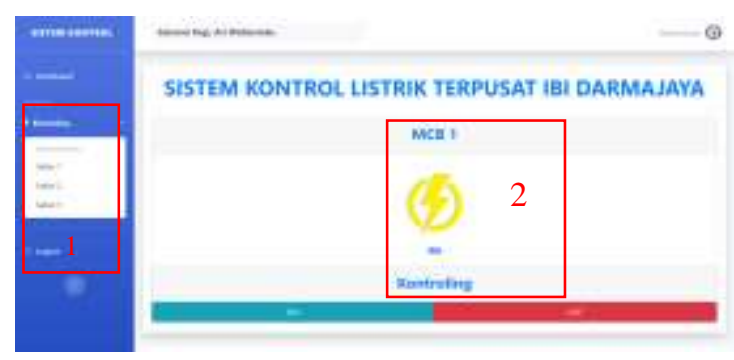

Gambar 6. Hasil Pengujian Sistem MCB $1 O N$ 
Pada gambar 6 (enam) dapat kita lihat bahwa pada kotak merah nomor 1 (satu) digunakan untuk memilih tombol saklar. Jika kita mengklik saklar 1 (satu) maka akan muncul tampilan MCB 1 (satu) seperti yang terlihat pada kotak merah nomor 2 (dua). Pada tampilan tersebut dapat kita lihat bahwa lampu dalam kondisi $O N$, sehingga kita dapat mengetahui bahwa pada gedung tersebut MCB 1 (satu) yang terpasang masih dalam

kondisi menyala. Apabila kita mengklik tombol OFF pada web browser maka akan akan muncul tampilan seperti pada gambar 7 (tujuh).

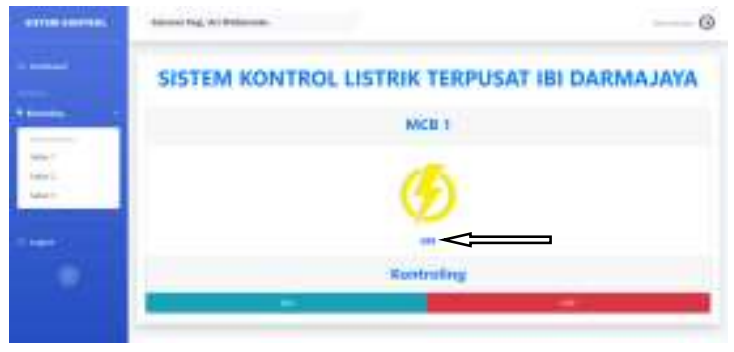

Gambar 7. Hasil Pengujian Sistem

\section{MCB 1 OFF}

Pada gambar hasil pengujian sistem MCB 1 dapat kita lihat bahwa setelah mengklik tombol OFF pada web browser tampilan yang tadinya $O N$ berubah menjadi $O F F$ seperti yang ditunjukkan oleh tanda panah pada gambar 7 ( tujuh). Dengan tampilan tersebut menandakan bahwa MCB 1 (satu) yang terpasang pada panel gedung dalam keadaan mati. Hal tersebut juga berlaku sama untuk saklar 2 (dua) dan saklar 3 (tiga).
Setelah melakukan pengujian sistem secara keseluruhan baik itu bada bagian software maupun hardware secara langsung pada sistem pengendalian listrik melalui MCB yang telah dibuat telah bekerja dengan baik dan dapat kita lihat hasil pengujian pada tabel berikut.

Tabel 1. Hasil Pengujian Sistem

\begin{tabular}{|c|c|c|c|c|c|c|c|}
\hline \multirow{2}{*}{$\begin{array}{l}\text { No. } \\
\text { Pengyjuan }\end{array}$} & \multicolumn{3}{|c|}{ Kondi Web Server } & \multicolumn{3}{|c|}{ Kondisi Panel Listrik } & \multirow{2}{*}{ Keterangan } \\
\hline & $\begin{array}{c}\text { Saklar } \\
1\end{array}$ & $\begin{array}{c}\text { Saklar } \\
2 \\
2\end{array}$ & $\begin{array}{c}\text { Saklar } \\
3\end{array}$ & $\begin{array}{c}\text { мсВ } \\
1 \\
1\end{array}$ & $\begin{array}{c}\text { МсB } \\
2 \\
\end{array}$ & $\begin{array}{c}\text { МСB } \\
3\end{array}$ & \\
\hline 1 & off & off & off & off & off & off & $\begin{array}{l}\text { Lampu mat, } A C \text { mati, } \\
\text { PC mati }\end{array}$ \\
\hline 2 & on & off & off & On & off & off & $\begin{array}{l}\text { Lampu hidup, AC mati, } \\
\text { PC mati }\end{array}$ \\
\hline 3 & on & on & off & On & on & off & $\begin{array}{l}\text { Lampu hidup, }, A C \\
\text { hidup, PC mati }\end{array}$ \\
\hline 4 & On & On & On & On & On & on & $\begin{array}{l}\text { Lampu hidup, AC } \\
\text { hidup, PC hidup }\end{array}$ \\
\hline
\end{tabular}

Pada tabel hasil pengujian sistem dapat kita lihat pengujian sistem dilakukan secara langsung dengan pengujian pertama semua saklar berapa pada kondisi off. Sehingga semua lampu indikator pada MCB pada kondisi off. Kemudian pengujian kedua yaitu mengklik saklar 1 (satu) menjadi on maka lampu indikator MCB 1 (satu) on, lampu indikator MCB2 (dua) dan MCB 3 (tiga) off. Pengujian ketiga saklar 1 (satu) dan saklar 2 (dua) pada kondisi on, maka lampu indikator MCB 1 (satu) dan MCB 2 (dua) dalam kondisi on. Pengujian terakhir dilakukan dengan menyalakan semua saklar pada kondisi on dan hasilnya semua lampu indikator pada MCB menyala atau dalam kondisi on. 


\section{SIMPULAN}

Dari hasil penelitian yang telah dilakukan dan telah di uji pada gedung laboratorium IIB Darmajaya dapat disimpulkan bahwa alat sistem kontrol listrik PLN terpusat bekerja sacara baik yang sesuai dengan rangcangan awal dan sesuai dengan fungsinya. Dengan diimplementasinya sistem ini maka pengontrolan dan monitoring listrik dapat dilakukan dari jarak jauh pada komputer yang telah dikonfigurasi. Petugas tidak perlu lagi berkeliling gedung untuk memeriksa dan memastikan on atau off pada setiap panel MCB yang terpasang. Adanya alat ini petugas dapat bekerja secara praktis dan efisien. Penelitian ini masih dapat di kembangkan untuk menjadi lebih fleksibel digunakan. Dengan cara menambahkan sistem IOT (Internet Of Thing) pada perangkat hardware. Di era rovolusi industri 4.0 dengan menerapkan IOT pada penelitian maka pengontrolan dan monitoring dapat dilakukan dimanapun dengan syarat perangkat kontrol terkoneksi dengan internet.

\section{DAFTAR PUSTAKA}

[1] Akbar Iskandar, Muhajirin, lisah., 2017, Sistem keamanan pintu berbasis arduino mega. Jurnal Informatika UPGRIS. Vol.3, No.2, hal 99-104.
[2] Novi Herawadi Sudibyo., 2014, Rancang bangun pengendali peralatan listrik pada gedung menggunakan jaringan nirkabel. Jurnal informatika. Vol. 14, No.2, hal 105-112.

[3] Fauzan M. \& Fiqiana P. Aplikasi Rumah Pintar (Smart Home) Pengendali Peralatan Elektronik Rumah Tangga Berbasis Web. Jurnal Teknologi Informasi dan Ilmu Komputer (JTIIK). Maret 2016; Vol. 3, No.1:51-58.

[4] Dimas Aditya Warman, Yuliarto Rahajo, Lukmanil Hakim., 2014, Rancang Bangun Alat Ukur Arus Menggunakan Transformator Arus Berbasis Mikrokontroler Atmega32. Jurnal Rekayasa dan Teknologi Elektro. Vol.8, No.2, hal 45-56.

[5] Pressman, R.S., 2012, Rekayasa Perangkat Lunak: Pendekatan Praktisi. Edisi 7. Andi Publisher, Yogyakarta.

[6] Budi Usmanto, Tri Susilowati., 2017, Perancangan prototype teknologi smart Building menggunakan arduino berbasis web Server untuk mendukung pembangunan Propinsi lampung menuju program lampung Smart city. Jurnal Informatika. Vol.17, No.2, hal 45-53. 